\title{
Community-based rehabilitation: an evaluation study
}

\author{
W GERSHON* \& G R SRINIVASAN† \\ *German Leprosy Relief Association, Postfach 1104 62, D-8700 \\ Würzburg, Germany; †German Leprosy Relief Association Rehabi- \\ litation Fund, 4 Gajapathy Street, Madras 600 030, South India
}

\section{Accepted for publication 2 July 1991}

Summary Leprosy gives rise to two types of stigmatization, one from the disease and its neuropathetic manifestations, with their resultant disability and handicaps, and the other due to social ostracism.

The process of rehabilitation should begin from the moment the disease is diagnosed, and the earlier its detection the better the prognosis for patients.

The family unit to which the patient belongs plays a vital role in his social life, ensuring and enhancing his self-respect and dignity in society, and this fact must be recognized when evolving a strategy for rehabilitation. In no circumstances should a patient be removed from his natural home environment.

It is important that the community is made leprosy conscious and gets more involved in hastening the social assimilation of patients. Communication plays an important role throughout the rehabilitation process. One of the major functions is the removal of the social stigma in the family and in the community and this involves communication skills to ensure interaction between the staff and patients' families and the education of the community.

A highlight of community-based rehabilitation is the excellent rate of repayment of loans by the patients to whom they were made. Also of note is the extent to which former defaulters make repayments due to the continous rapport and good interpersonal relationship between the staff and patients.

Most of the subjects of this study were drawn from the lower economic strata of society and for them the most essential consideration is to make a living, however meagre. This problem is augmented in the case of leprosy sufferers, not only because of the fear and hostility which their disease excites in others, but because of their deformity and handicap. No rehabilitation programme can afford to ignore these factors which so seriously disturb the normal life of patients.

\section{Introduction}

For centuries, rehabilitation was considered merely as an act of charity. Tracing the history of rehabilitation in leprosy we find that it originated in the 14th century in Europe and then spread to other countries. At that time the Order of Lazarus was founded to help 
leprosy sufferers; there was no effective treatment and they were treated as outcasts and were given horns, clappers and bells and known as 'horn brothers'.

Historically therefore the Lazarus homes of 14th century Europe were the forerunners of the present rehabilitation homes and projects. Times have changed. Today medical treatment combats the vagaries of leprosy, the drugs are readily available and have been proved effective and the disease can be cured and its spread contained. The principles of reconstructive surgery applied in other spheres have been tried in leprosy and found successful. Consequently, these developments have together revolutionized both the prognosis for the individual patient and public opinion concerning leprosy and the rehabilitation of those who suffer from it. Rehabilitation is now considered an essential component of the health care delivery system designed for the management and control of leprosy and, following modern scientific and technological advances, it has incorporated an element of social science, drawing up an objective and realistic plan of action for every patient from the moment he is diagnosed and registered for treatment. This plan goes hand-in- hand with all therapeutic and surgical procedures and forms an essential thread running through the whole treatment and eradication programme.

\section{The present study: its background and purpose}

In the Greater Madras Leprosy Treatment and Health Education Scheme (GREMALTES) large numbers of patients were registered, and it became necessary to include rehabilitation as a component in the scheme. The total number of cases in 1971-74 was 12,000 and by 1983 this had risen to 27,000. The German Leprosy Relief Association (GLRA) made a study of the conventional rehabilitation centres colonies, sheltered workshops and infirmaries, which have huge capital and recurrent financial expenditure. The institutionalization of leprosy patients was seriously questioned because of the detrimental effect of such segregation and isolation on their personality. After weighing up all the pros and cons, the GLRA conceived a new concept: domiciliary or communitybased rehabilitation. A proposal was submitted by the Regional Secretariat of GLRA in India to the headquarters in Germany and they agreed to finance a pilot programme in the City of Madras. A new society, the 'German Leprosy Relief Association Rehabilitation Fund' was registered in India under the Societies Registration Act.

The aim of the rehabilitation scheme was to create opportunities for self-employment, open employment or job placement and jobs in sheltered workshops. Added to this was financial assistance to the relatives of the patients with severe disabilities unable to work to help them start in trade or to find employment, so that they could support the disabled - this was known as 'indirect rehabilitation'.

The GLRA provided the necessary core fund to give interest-free loans to patients to help them start new trades or occupations and in due course the nationalized banks came forward to give loans at a low rate of interest to patients recommended by the social workers in the programme.

Training and placement activities were also undertaken. The social workers were in contact with various job training centres and small industrial units and were therefore able to get patients trained and employed. The scheme also undertook the education of the children of patients, and service clubs-like the Rotary and the Lions-came forward to support this. 
Recognizing the potential advantage of the association of social science with leprosy control, the GLRA found a role in the programme for qualified social workers and they have proved to be useful members of the team by virtue of their professional training and interdisciplinary approach to problems and the ways and means of solving them.

The study was designed to evaluate the impact of the programme and to assess the associated problems in Madras City in the period 1974-83.

\section{The selection of the study group}

From the beginning of 1974 to 1983 , a total of 972 leprosy patients were rehabilitated under this programme:

\begin{tabular}{lc} 
Self-employment through GLRA funds & 407 \\
Self-employment through nationalized banks & 202 \\
Open employment and sheltered workshops & 363 \\
\cline { 2 - 2 } & 972 \\
\hline
\end{tabular}

Out of this total, 78 were selected by a stratified random sampling method. A numbered list was obtained from the scheme and the first batch were drawn by lot. Every tenth person was selected from the self-employed group and every twentieth from the open employed group (see Table 1).

\section{Data collection}

The rehabilitated patients were the primary source of data and the social and follow-up workers were the secondary source. The files, records and books maintained in the office were the documentary source.

As many patients were illiterate and needed an interpretation and explanation to some of the questions an interview schedule was used. An interview guide was used to collect data from the staff. Both these tools were finalized only after a feasibility study involving field visits and discussions with rehabilitation officers and others and pretesting on 6 persons, 2 from each group.

Table 1. Number of patients in evaluation study

\begin{tabular}{lcc}
\hline Programme & Number & Percentage \\
\hline Self-employed with GLRA funds & 40 & $51 \cdot 28$ \\
Self-employed through nationalized banks & 20 & $25 \cdot 64$ \\
Open employment & 12 & $15 \cdot 39$ \\
Sheltered workshops & 6 & $7 \cdot 69$ \\
\hline$\quad$ Total & 78 & $100 \cdot 00$ \\
\hline
\end{tabular}


The data collection was by interviewing patients in their homes or places of work. The evaluation was limited to rehabilitated patients and did not include beneficiaries under the 'indirect rehabilitation scheme', i.e. the relatives of patients.

It can be seen in Table 1 that more than half of the group were rehabilitated through the self-employment scheme funded by GLRA, while the banks helped just over one quarter. The other programmes helped some $15 \%$ and $7 \cdot 5 \%$ respectively.

\section{Evaluation of the impact of the programme}

Sex: There were 61 males and 17 females.

Age: 46 (59\%) were in the age group 21-40 and 29 in the $41-50$ and above age group; 75 were over 31 years of age. The programme was open to all irrespective of age and sex.

Marital status: $56(71 \cdot 79 \%)$ were married, 13 (16.67\%) unmarried, 5 were widowed and 4 separated.

Education: $21(34 \cdot 62 \%$ ) had primary school education, 20 (over one quarter) secondary, 9 $(11 \cdot 54 \%)$ high school and only 3 had university education. However $19(24 \cdot 35 \%)$ were illiterate.

Duration of the disease: $51(65 \cdot 38 \%)$ had had leprosy for over 10 years, 20 between 5 and 10 years and 7 for less than 5 years.

Treatment status: $67(85.9 \%)$ were still under treatment and the remainder having completed the prescribed course of chemotherapy had stopped treatment on the advice of their doctor.

Family size: In 30 there were less than 3 family members, in $364-6$ members and in 12 there were more than 6 members.

Leprosy in the family: $66(84.62 \%)$ said that no one else in the family was affected and 12 that there were one or more other cases.

\section{Reactions of the patients to the disease}

At the time of diagnosis

Only 6 were reconciled to the fact that they had leprosy, 29 were unhappy and expressed sorrow about it and 4 did not accept the diagnosis. Twenty-one considered themselves neglected by others and 18 had suicidal feelings. Generally these reactions were an indication of their underlying fear and irrational attitude.

\section{After rehabilitation}

Sixty have accepted the fact that they have to live with their disease, the remaining 18 are still not reconciled to it even after rehabilitation. Possibly this is the same group that had suicidal feelings at the time of diagnosis. It is a sad irony indeed that the programme has not helped them change their attitude.

\section{Respect and recognition in the family}

Before rehabilitation $65(83 \cdot 3 \%)$ were respected and $13(16 \cdot 67 \%)$ were not.

After rehabilitation $74(94 \cdot 87 \%)$ were respected and only 4 were not. It appears 
therefore that the programme has enhanced the level of respect accorded to leprosy patients in their family.

\section{Occupational status}

Before rehabilitation $21(26 \cdot 97 \%)$ were unemployed and a further 7 lost their jobs. Fifty patients had various occupations.

After rehabilitation none was unemployed and all had some kind of occupation. An essential aspect of the programme involved change and adaptation of occupation to take account of the physical condition of the patient, his handicap and in addition his aptitude. The social workers played a key role in motivating patients to accept such changes for their own good, so helping them to live with their disability.

\section{Economic benefit}

The applications of loans made available to patients were:

\begin{tabular}{lrr} 
to reactivate traditional occupations: & 8 & $(13 \cdot 33 \%)$ \\
to start new business: & 32 & $(53 \cdot 34 \%)$ \\
to improve old business: & 20 & $(33 \cdot 33 \%)$ \\
& & \\
\cline { 2 - 3 } & Total & $60(100 \cdot 00 \%)$
\end{tabular}

The average monthly income of the patients before and after rehabilitation is shown in Table 2.

It is of note that more than one sixth of the group had no income whatever before rehabilitation. Certain changes can be seen; while the percentage of those earning less than RS 200 per month has come down from $51 \cdot 29$ to $15 \cdot 38 \%$, those earning up to RS 399 per month has increased from $15 \cdot 38$ to $44.88 \%$, those earning up to RS 599 per month has increased from 8.97 to $21.7 \%$ and those earning RS 600 and over per month has increased

Table 2

\begin{tabular}{|c|c|c|c|c|}
\hline \multirow{2}{*}{$\begin{array}{l}\text { Income } \\
\text { (Indian Rupees)* }\end{array}$} & \multicolumn{2}{|c|}{ Before rehabilitation } & \multicolumn{2}{|c|}{ After rehabilitation } \\
\hline & Number & $(\%)$ & Number & $(\%)$ \\
\hline Nil & 12 & $15 \cdot 39$ & 6 & $7 \cdot 69$ \\
\hline Less than 200 & 40 & $51 \cdot 29$ & 12 & $15 \cdot 38$ \\
\hline $200-399$ & 12 & $15 \cdot 38$ & 35 & $44 \cdot 88$ \\
\hline $400-599$ & 7 & 8.97 & 17 & $21 \cdot 79$ \\
\hline 600 and above & 7 & 8.97 & 8 & $10 \cdot 26$ \\
\hline Total & 78 & $100 \cdot 09$ & 78 & $100 \cdot 00$ \\
\hline
\end{tabular}

\footnotetext{
$* 1 \mathrm{US} \$=\mathrm{RS} 10.40$ in 1982.
} 
Table 3

\begin{tabular}{lccccr}
\hline & \multicolumn{2}{c}{ Before rehabilitation } & & \multicolumn{2}{c}{ Af ter rehabilitation } \\
\cline { 2 - 3 } \cline { 6 - 6 } $\begin{array}{l}\text { Value of assets } \\
\text { Indian Rupees) }\end{array}$ & Number & $(\%)$ & & Number & $(\%)$ \\
\hline No assets & 46 & $58 \cdot 97$ & & 19 & $24 \cdot 35$ \\
Less than 10,000 & 11 & $14 \cdot 10$ & & 17 & $21 \cdot 80$ \\
$10,001-20,000$ & 13 & $16 \cdot 67$ & & 19 & $24 \cdot 35$ \\
$20,001-30,000$ & 8 & $10 \cdot 26$ & & 6 & $7 \cdot 70$ \\
30,001 and above & 0 & 0 & & 17 & $21 \cdot 80$ \\
\hline \multicolumn{1}{c}{ Total } & 78 & $100 \cdot 00$ & & 78 & $100 \cdot 00$ \\
\hline
\end{tabular}

from 8.97 to $10 \cdot 26 \%$. There has clearly been an all-round improvement in the level of income and earning capacity after rehabilitation: however there are disappointing failures, notably $7 \cdot 6 \%$ of patients still had no income after rehabilitation.

The value of the patients' assets before and after rehabilitation is shown in Table 3 . It is observed that more than half did not have any assets whatever before rehabilitation, but that this proportion was appreciably reduced afterwards (from 58.97 to $24.35 \%$ ). Increases are observed at all levels, but of special note is that before rehabilitation there were no patients with assets in excess of 30,000 , but afterwards there were 17. This indicates that rehabilitation enabled patients with some income to augment them considerably.

THE LOANS MADE AVAILABLE

Of 60 patients studied, 40 with loans from GLRA and 20 with loans from nationalized banks, 31 were regular in repaying the loan and 29 were iregular.

Of 60 patients receiving loans from either GLRA or the banks 42 were satisfied and 28 were dissatisfied with the scheme. The reasons for dissatisfaction were insufficiency of the amounts advanced to meet all their needs and expectations.

\section{SAVINGS AFTER REHABILITATION}

Twenty-three patients, a little over one quarter of the group, said they were able to save, but 55 said they could save nothing from their income.

\section{HOUSING}

The study showed that before rehabilitation 39 were living in rented houses, 23 in their own houses, 3 in slum clearance board tenements, 9 in houses built on unauthorized land and 4 in leprosy beggar rehabilitation homes. After rehabilitation 39 were staying in rented houses. There was a marginal increase in the number of those owning housesfrom 23 to 31 . The number of patients living in slum clearance board tenements came down to 2 , those living in houses built on unauthorized land came down to 6 and the 4 
patients living in the leprosy beggar houses found housing elsewhere. This shows a marked improvement in housing after rehabilitation.

\section{PROBLEMS ENCOUNTERED BY THE BENEFICIARIES}

Under the self-employment scheme: 23 had no problems, 12 had an inadequate income, 9 complained of lack of help from other family members, 7 expressed unsteady business and 9 had health problems.

Under the open-employment and sheltered workshop scheme: 10 had no problems, but the remaining 8 had various complaints: a high workload for low pay, irregular work and difficulties with management.

\section{Effectiveness of the scheme}

Forty said it was effective in helping them meet the needs of their entire family, 14 found it partially effective for family needs, 12 effective for individual needs only and 12 found it ineffective.

\section{Helpfulness of the rehabilitation department}

Fifty-nine found the services helpful, 10 very helpful and 3 extremely helpful. Only 6 said that they were not helpful (inevitably there are always some who cannot be satisfied).

Table 4. German Leprosy Relief Association Rehabilitation Fund, Madras/India, 1974-83. Number of patients rehabilitated under various schemes

\begin{tabular}{|c|c|c|c|c|c|c|c|}
\hline No. & Centre & $\begin{array}{c}\text { Year } \\
\text { established }\end{array}$ & $\begin{array}{l}\text { Loans } \\
\text { through } \\
\text { GLRA }\end{array}$ & $\begin{array}{c}\text { Loans } \\
\text { through } \\
\text { banks }\end{array}$ & $\begin{array}{c}\text { Job } \\
\text { placements }\end{array}$ & $\begin{array}{c}\text { Other } \\
\text { welfare }\end{array}$ & Total \\
\hline 1 & Madras (urban) & 1974 & 407 & 202 & 363 & 591 & 1563 \\
\hline 2 & Vishakapathnam (urban) & 1974 & 100 & 27 & 97 & 299 & 523 \\
\hline 3 & Jhargram (rural) & 1974 & 11 & - & - & - & 11 \\
\hline 4 & Kumbakonam (rural) & 1979 & 132 & 176 & 107 & 405 & 820 \\
\hline 5 & Pullambady (rural) & 1979 & 103 & 28 & 6 & 993 & 1130 \\
\hline 6 & Chettupattu (rural) & 1979 & 173 & 3 & 11 & 16 & 203 \\
\hline 7 & Bombay (urban) & 1980 & 118 & 8 & 13 & 35 & 174 \\
\hline 8 & Tutucorin (rural) & 1981 & 25 & 6 & 11 & 9 & 51 \\
\hline 9 & Nilakottai (rural) & 1983 & 35 & - & - & - & 35 \\
\hline 10 & Palamner (rural) & 1983 & 22 & - & 5 & - & 27 \\
\hline 11 & Bijapur (urban) & 1983 & - & 27 & - & - & 27 \\
\hline \multicolumn{2}{|c|}{ Total } & & 1126 & 477 & 613 & 2348 & 4564 \\
\hline
\end{tabular}

Note: Other welfare activities: include education of the leprosy patients and other needs. 


\section{Social consequences of rehabilitation}

Sixty-seven patients of this study were undergoing treatment and included both infectious and noninfectious types of leprosy and some with deformities and handicaps. Before rehabilitation, some were employed in various services, some self-employed and some unemployed. A change of occupation had been necessary in some because of their physical disability or the attitude of the coworkers to their disease. As a result they suffered a reduction in their income and in some cases were unemployed at the time of rehabilitation. In a typical case, a father with family responsibilities, soon after becoming aware of having leprosy not only loses his job but also his self-confidence and interest in his family. As his income falls, his dependence on the help and charity of his already poor relatives increases, until his situation becomes desperate. It is at this point that the GLRA Rehabilitation Scheme is of obvious and dramatic benefit.

\section{The extension of the rehabilitation programme}

Following the encouraging results of this scheme in Madras, similar projects were developed between 1974 and 1983 in 4 urban areas and 7 rural areas in India, assisting a total of 2216 leprosy patients. Details are given in Table 4. 


\title{
Réadaptation au sein de la communauté: une évaluation
}

\author{
W Gershon et G R Srinivasan
}

Résumé La lèpre cause deux types de stigmatisation, l'une due à la maladie et à ses manifestations neuropathiques avec pour résultat infirmités et handicaps et l'autre causée par l'ostracisme social. Le processus de réadaptation doit commencer dès que la maladie est diagnostiquée et le pronostic des patients est d'autant meilleur que la maladie est dépistée dans les premiers stages. La cellule familiale du patient joue un rôle prépondérant dans sa vie sociale; elle garantit et renforce le respect qu'il a de lui-même et sa dignité au sein de la société. Il faut en tenir compte lors de la mise au point d'une stratégie de réadaptation. En aucun cas faut-il enlever un patient de son cadre familial naturel. Il est important que la communauté prenne conscience de la lèpre et s'efforce d'accélérer l'assimilation sociale des patients. La communication joue un rôle important dans le processus de réadaptation. Une des tâches les plus importantes est le retrait du stigmate social au sein de la famille et de la communauté et ceci nécessite des compétences en matière de communication qui garantissent une interaction entre le personnel et la famille du patient et l'éducation de la communauté.

Le grand nombre de prêts remboursés par les patients auxquels ils avaient été accordés, constitue une des réussites de la réadaptation au sein de la communauté. Il convient également de noter l'ampleur des remboursements effectués par les débiteurs, résultat des rapports continus et des bonnes relations entretenues entre le personnel et les patients.

La plupart des sujets de cette étude appartiennent aux groupes socio-économiques les moins privilégiés et ce qui leur importait le plus c'est de gagner leur vie, aussie lamentable soit elle. Ce problème est exacerbé dans le cas des lépreux tant à cause de la peur et de l'hostilité que leur maladie suscite qu'à cause de leurs difformités et handicaps. Aucun programme de réadaptation ne peut se permettre d'ignorer ces faits qui affectent profondément la vie quotidienne des patients.

\section{La rehabilitación basada en la comunidad: un estudio de evaluación}

\author{
W Gerson y G R SRinivasan
}

Resumen La lepra produce dos tipos de estigmatización: una que resulta de la enfermedad y sus manifestaciones neuropatéticas, con la incapacidad y minusvalía que resultan, y la otra, debido al ostracismo social. El proceso de rehabilitación debe comenzar en el momento del diagnóstico de la enfermedad, y cuando antes se detecta mejor resulta el prognosis para el paciente. La unidad familial a la cual perteneceel paciente juega un papel vital en su vida social, asegurando y realzando su amor propio y su dignidad en la sociedad, y se debe reconocer este hecho cuando se prepara una estrategia para la rehabilitación. Jamás se debe retirar el paciente de su ambiente natural de casa. Es importante que la comunidad se haga más consciente de la lepra y se implique más en acelerar la asimilación social del paciente. La comunicación jeuega un papel importante en todo el proceso de asimilación. Una de las funciones más importantes es eliminar el estigma social en la familia y en la comunidad, y esto requiere habilidades de comunicación para asegurar una interacción entre el personal y las familias del paciente, y la educación de la comunidad.

Un punto sobresaliente de la Reeducación basada en la Comunidad, es la excelente proporción de reintegros de parte de los pacientes que los recibieron. También es importante el número de incumplidos que reembolsaron posteriormente, debido a la buena compenetración que existe entre el personal y los pacientes.

La mayoría de los pacientes que participaron en este estudio fueron de niveles económicos inferiores de la sociedad, y para ellos lo mas esencial es ganarse la vida, por pobre que sea. Este problema es mas serio en el caso de los que suf ren de la lepra, no solamente por el temor y la hostilidad que estimula su enfermedad en los demás, pero también por su deformidad y minusvalia. Ningún programa de rehabilitación puede pasar por alto estos factores que en forma tan seria trastornan la vida normal de los pacientes. 